\title{
Ma Tribu: Un portrait sans totem ni tabou
}

\author{
by Jacques Henripin \\ Montreal: Éditions Liber 2011 \\ ISBN: 978-2895782919 \\ Paperback, \$20.00, 162 pp. \\ Reviewed by Gilles Paquet \\ Centre on Governance, University of Ottawa \\ gilles.paquet@uottawa.ca
}

Jacques Henripin has acquired a lustrous reputation in Canada and abroad, but in Quebec he is nothing less than an iconic figure in demography and the social sciences-so much so that his name could be mentioned casually in the 1986 blockbuster film The Decline of the American Empire, without any need to explain who he was. He has published widely in scientific journals and more general periodicals on general demography, fertility, demolinguistics, and diverse aspects of population policy.

His approach has always been rigorous but eclectic and courageous - never hesitating to be a contrarian when the data would appear to support policy stands that were not in good currency, and to change his mind when new evidence would prove his earlier prognostications to be questionable.

Over the years, Henripin became entangled in polemics. He never shied away from sharing his views in the media and in journals of opinion. His contributions to the debates on law 101, on the status of women, on the impact of ageing on pension regimes, on all aspects of the fertility issue, on demolinguistics and the anglicization of Montreal, and many other controversial topics have always been carefully articulated and prudently propounded. His economics background has also led him to routinely underline the key opportunity costs and trade-offs in all of those files.

After a long and fruitful academic career, Henripin formally retired from his university post in the mid1990s. This has not stopped the flow of production of academic and policy outputs- he published a book on population policy in the mid-2000s_-but it also provided him with an opportunity to develop a new genre of writing. He published two books permeated with demography but mainly focused, in the first case, on personal souvenirs and reflections (Souvenirs et refflexions d'un ronchon. Montreal: Varia 1998), and, in the second case, on his perspectives as a public intellectual — a most interesting and baroque book (Ma tribu: Un portrait sans totem ni tabou. Montréal: Liber 2011). This latter book is the one of interest here.

It is a publication strongly demography-based in its first part — where, in the first seven chapters, he provides a synthetic and most helpful portrait of the demographic situation of French Canada and Quebec, together with a running commentary on some unpleasant, or less well known, features of this situation and on the challenges they create. In the last two-thirds of the book, Henripin presents a series of vignettes or essays on different aspects of the Quebec socio-economy and intellectual landscape that have been a source of concern for him, and that he analyzes skillfully and surgically.

In the first part, the occasional caustic statements are only meant to mark the beat of analysis by Henripin the demographer — he mainly explains forcefully and graphically. In the second part, one discovers Henripin the social critic, and the tone is more acid and at times denunciatory: Henripin the public intellectual (although he would be repulsed by this label) focuses his attention on various sores on the underbelly of Quebec society and mercilessly exposes them sans retenue. Both parts are interesting and useful for different reasons.

The first seven chapters of the book define the 'tribe' of interest to Jacques Henripin-the French Canadians. He then sketches the growth profile of a population of 70,000 in 1760 to become 6.5 million in 1981 as 
largely due to a natural increase that roughly doubled the population every thirty years or so between 1760 and 1875. Afterward, fertility diminished slowly at first, and then dramatically, so that between 1950 and 1970 the fertility rate per woman had dropped to 1.7 child-i.e., 20 per cent less than what would be required to ensure population replacement.

Henripin shows that if this low fertility persists, but a significant majority of allophone immigrants adopts French as their main language (as they have done in the recent past), then we may conjecture that the French Canadians will still remain an overwhelming majority of the population in Quebec in the middle of the present century.

Henripin then addresses the problem of ageing of the Quebec population, and the ways in which its deleterious effects might be countered. By 2050, 30 per cent of the population of Quebec will be over 65. As a result, there will be an increase of 70 to 85 per cent in public healthcare costs per worker between 2000 and 2040 because of ageing; and if the present pension regime is maintained, its burden by 2040 might be some 23 per cent of the wage bill of workers. This is going to be such a heavy load that to contain this increasing burden on the workforce, there will be pressure to increase fertility, increase labour force participation, extend the length of working life, and raise the retirement age.

One radical suggestion put forward by Jacques Henripin to increase labour force participation is a better streaming of students - away from the so-called advanced studies (and programs where so many students are wasting their time in endeavours they will never successfully complete) toward technical trades education where they could thrive and be productive.

Can immigration help in meeting the challenges created by an ageing population? On this point, Henripin simply states that he does not feel that the impact can be important. Benoit Dubreuil and Guillaume Marois (Le remède imaginaire: Pourquoi l'immigration ne sawvera pas le Québec. Montréal: Boréal 2011) have recently made the same point in a blunter way.

The next thirteen chapters present short, loosely connected essays on toxic aspects of the French Canadian world: some are about institutions (family, economy); many are about wicked problems at the source of ethereal debates that have been handled in ways that have aggravated Henripin (language, culture, values, right-left categories, nationalism, secession, and ecologism); and a few are about flawed organizations (educational bureaucracy, unions, political apparatus, media).

In dealing with institutions, Henripin's discourse remains very clinical, if not dispassionate. On the family, Henripin records all the elements that have made it more fragile, and show how these factors have been an important source of the crisis of fertility. On the economy, he sketches a most damning and well-documented portrait of the sources of non-productivity of French Canadians: relatively speaking, they work less, are less educated, and less well equipped, but also their public servants are less efficient, and the state intervenes actively to promote much waste and inefficiency.

In dealing with the wicked problems and the ethereal debates about the myths and ideologies in good currency that such debates have produced, the tone ranges from nostalgic sadness when dealing with the poverty of the language-in-use and of what now passes for French Canadian culture and values, to intellectual torment in the face of the intellectual vacuity that presides over the debates about right-left manicheanism, nationalism, secession, and ecologism. In those latter chapters, his impatience shows, the language is sharper, and the style becomes progressively more acerbic in the face of blatant intellectual dishonesty, willful blindness, and the gospels of numerous secular religions.

When dealing with some of the flawed organizations to which Henripin ascribes much of this mess, the tone is even more pointed. The anger is palpable when he denounces the 'pedocrats' responsible for the damnation of the education system, or the unions representing the aristocracy of labour and sharing the 'Bolshevik attitudes' of the bureaucrats. In dealing with politicians, Henripin cannot avoid communicating his sense of despair in the face of the colossal ignorance and lack of imagination that mars the conduct of public affairs in his tribe.

Quite fittingly, Henripin's last chapter (before a short and somewhat perfunctory conclusion) deals with the media. Although Henripin is careful to identify journalists and columnists who live up to their burden of office, he ascertains that the vast majority of them are mainly generating disinformation, bunk, confusion, and ideology_all this with much self-righteousness and in a most sanctimonious way. 
The first section of this book provides a very succinct and most informative and realistic portrait of the demographic situation of French Canadians and Quebec. The second section of the book is a very perceptive, provocative, and insightful series of vignettes in which Henripin challenges the conventional wisdom with intelligence and gusto. In a lively style, this book brings sharp critical thinking to issues that have been systematically occluded, or ideologically transmogrified for decades by the ruling intelligentsia.

This book is a breath of fresh air that does much to debunk the foundations of the real Grande Noirceur in Quebec - not the one that has been wrongly presumed to have existed before 1960 by too many ill-informed observers, but the one that has crippled intellectual debates in much of French Canada in the more recent past. 